\title{
Successful, safe and sustainable cities: towards a New Urban Agenda
}

\section{Commonwealth Journal of Local Governance}

Issue 19: December 2016

http://epress.lib.uts.edu.au/ojs/index.php/cjlg

\section{David Satterthwaite}

International Institute for Environment and

Development

United Kingdom

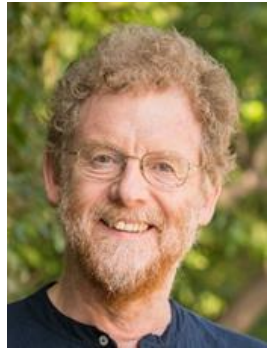

\begin{abstract}
There is a growing interest among national governments and international agencies in the contribution of urban centres to sustainable development. The paper outlines the new global agendas to guide this: the Sustainable Development Goals, the Paris Agreement and the New Urban Agenda. It then sets out the key challenges and opportunities facing urban governments across the Commonwealth in implementing these agendas and achieving inclusive, safe, resilient and sustainable cities. This is hampered by significant infrastructure deficits (especially in provision for water and sanitation) and a lack of funding. After outlining the commitments agreed by national governments in these global agendas, the paper discusses the vital role in meeting those of city leadership, financing and investment, urban planning and local economic development. Whilst it is good to see recognition of the importance of cities to national economies, economic success in any city does not automatically contribute to a healthier city, a more inclusive city or a sustainable city. This needs capable and accountable urban governments working closely with local civil society, and the redirection of public funds and development assistance to support them.
\end{abstract}

\section{Introduction}

There is a new interest in cities by many national governments and international agencies from three perspectives. The first is the recognition of their economic importance - for attracting investment and innovation in national and regional economies. The second is in the healthy living conditions and high quality of life cities can provide, if they are well governed. The third is in their potential to delink a high quality of life from high greenhouse gas emissions and thus contribute to avoiding dangerous

(C) 2016 David Satterthwaite. This is an Open Access article distributed under the terms of the Creative Commons Attribution 4.0 Unported (CC BY 4.0) License (https://creativecommons.org/licenses/by/4.0/), allowing third parties to copy and redistribute the material in any medium or format and to remix, transform, and build upon the material for any purpose, even commercially, provided the original work is properly cited and states its license. 
climate change. Table 1 summarises how the negative views of cities has given way to more positive perspectives.

Table 1: How cities are viewed

\begin{tabular}{|l|l|}
\hline Negative & Positive \\
\hline Parasites on the economy and on rural areas & $\begin{array}{l}\text { Leading innovation, social justice and economic } \\
\text { success }\end{array}$ \\
\hline $\begin{array}{l}\text { Centres that concentrate and generate air and } \\
\text { water pollution }\end{array}$ & $\begin{array}{l}\text { Centres with the healthiest populations and low levels } \\
\text { of air and water pollution }\end{array}$ \\
\hline Drivers of climate change & $\begin{array}{l}\text { Centres that reconcile high quality of life with low } \\
\text { greenhouse gas emissions }\end{array}$ \\
\hline Concentrations of poverty, inequality and violence & $\begin{array}{l}\text { Centres for inclusive development in livelihoods, basic } \\
\text { services, governance and empowerment }\end{array}$ \\
\hline
\end{tabular}

While there are examples of innovative cities or city-communities that validate the positive perspectives and contribute to sustainable development, there are also many examples of urban centres which meet few, if any, of the criteria for sustainable development. There are also very large deficits in provision for basic infrastructure and services. Cities provide so many agglomeration economies that lower the costs of achieving the positive aspects - but these depend on urban governments taking advantage of these lower costs, and which have the capacity to work with their populations. So many urban governments have little or no investment and technical capacity to do so (United Cities and Local Governments 2014).

Over the past year and a half, there have been three new sets of global agreements that have great relevance for city and municipal governments; the Sustainable Development Goals (SDGs), ${ }^{1}$ the Paris Agreement $^{2}$ and the New Urban Agenda. ${ }^{3}$ But while the many commitments in these have been developed and agreed by national governments, many fall within the responsibilities of local governments. National governments committed to a comprehensive and ambitious set of goals within the SDGs and the Paris Agreement - but with little said about who has to act and how these will be financed. The New Urban Agenda agreed at the UN Conference on Housing and Sustainable Urban Development in October 2016 was meant to address this gap - but it failed to do so.

\section{The Sustainable Development Goals (SDGs) and urban development}

The SDGs bring a very ambitious range of goals that are relevant for rural and urban development and for global issues. Human development is central to the SDGs; so too is the elimination of extreme poverty and hunger, reduction of all poverty and 'leaving no-one behind'. The SDGs recognise the

\footnotetext{
1 The Sustainable Development Goals, officially known as Transforming our World: the 2030 Agenda for Sustainable Development is a set of 17 goals and 169 targets that succeed the Millennium Development Goals, agreed at the UN Sustainable Development Summit in September 2015.

2 The Paris Agreement is an agreement within the United Nations Framework Convention on Climate Change signed in April 2016.

3 The New Urban Agenda is the outcome document agreed at the UN Conference on Housing and Sustainable Urban Development in Quito, in October 2016.
} 
importance of having goals that focus on urban issues. They also include goals and targets relevant to disaster risk reduction, climate change adaptation and climate change mitigation in urban areas and even a recommendation that responds to the need for these to be integrated.

The Global Taskforce of Local and Regional Governments (GTF) ${ }^{4}$ and the Sustainable Development Solutions Network successfully campaigned for the inclusion of a specific stand-alone goal on sustainable urbanisation in the 2030 Agenda. SDG 11 calls on all actors to "make cities and human settlements inclusive, safe, resilient and sustainable" and has ten targets covering areas such as housing, transport, air quality and waste management among others (see Box 1).

\section{Box 1: SDG Goal 11 Make cities and human settlements inclusive, safe, resilient and sustainable Targets:}

11. 1 By 2030, ensure access for all to adequate, safe and affordable housing and basic services and upgrade slums

11.2 By 2030, provide access to safe, affordable, accessible and sustainable transport systems for all, improving road safety, notably by expanding public transport, with special attention to the needs of those in vulnerable situations, women, children, persons with disabilities and older persons

11.3 By 2030, enhance inclusive and sustainable urbanization and capacity for participatory, integrated and sustainable human settlement planning and management in all countries

11.4 Strengthen efforts to protect and safeguard the world's cultural and natural heritage

11.5 By 2030, significantly reduce the number of deaths and the number of people affected and substantially decrease the direct economic losses relative to global gross domestic product caused by disasters, including water-related disasters, with a focus on protecting the poor and people in vulnerable situations

11.6 By 2030, reduce the adverse per capita environmental impact of cities, including by paying special attention to air quality and municipal and other waste management

11.7 By 2030, provide universal access to safe, inclusive and accessible, green and public spaces, in particular for women and children, older persons and persons with disabilities

11.a Support positive economic, social and environmental links between urban, peri-urban and rural areas by strengthening national and regional development planning

11.b By 2020, substantially increase the number of cities and human settlements adopting and implementing integrated policies and plans towards inclusion, resource efficiency, mitigation and adaptation to climate change, resilience to disasters, and develop and implement, in line with Sendai Framework for Disaster Risk Reduction 2015-2030, holistic disaster risk management at all levels

11.c Support least developed countries, including through financial and technical assistance, in building sustainable and resilient buildings utilising local materials

Source: United Nations (2015) Transforming our World: the 2030 Agenda for Sustainable Development

\footnotetext{
${ }^{4}$ The Global Taskforce of Local and Regional Governments is a coordination mechanism bringing together the major networks of local government to undertake joint advocacy relating to international policy processes.
} 
The SDGs relevant to human development and poverty reduction are mostly national goals - and so are assumed to include urban populations. They include:

- Universal provision for risk-reducing infrastructure by 2030: 6.1, achieve universal and equitable access to safe and affordable drinking water for all; 6.2, achieve access to adequate and equitable sanitation and hygiene for all and end open defecation, paying special attention to the needs of women and girls and those in vulnerable situations.

- Universal provision for services by 2030: 7.1, ensure universal access to affordable, reliable and modern energy services; 1.3, implement nationally appropriate social protection systems and measures for all, including minimum floors, and achieve substantial coverage of the poor and the vulnerable; 1.4, ensure that all men and women, in particular the poor and the vulnerable, have equal rights to economic resources, as well as access to basic services, ownership and control over land and financial services; 3.8, achieve universal health coverage, including financial risk protection, access to quality essential health-care services and access to safe, effective, quality and affordable essential medicines and vaccines for all; 4.1, ensure that all girls and boys complete free, equitable and quality primary and secondary education; and 11.2, provide access to safe, affordable, accessible and sustainable transport systems for all.

- Universal housing: 11.1 by 2030 , ensure access for all to adequate, safe and affordable housing and basic services and upgrade slums.

- The rule of law: 16, promote peaceful and inclusive societies for sustainable development, provide access to justice for all and build effective, accountable and inclusive institutions at all levels; 16.3, promote the rule of law at the national and international levels and ensure equal access to justice for all; and 16.9 by 2030 , provide legal identity for all, including birth registration.

- Voice/participation/government accountability to citizens: 11.3 by 2030 , enhance inclusive and sustainable urbanisation and capacity for participatory, integrated and sustainable human settlement planning and management in all countries; 16.6, develop effective, accountable and transparent institutions at all levels; 16.7, ensure responsive, inclusive, participatory and representative decision-making at all levels; 16.10, ensure public access to information and protect fundamental freedoms, in accordance with national legislation and international agreements.

- Decent work and livelihood opportunities: 8.3, promote development-oriented policies that support productive activities, decent job creation, entrepreneurship, creativity and innovation, and encourage the formalisation and growth of micro-, small- and medium-sized enterprise; 8.5 by 2030 , achieve full and productive employment and decent work for all women and men, including young people and persons with disabilities; 8.8, protect labour rights and promote safe and secure working environments for all workers; 4.4 by 2030 , substantially increase the 
number of youth and adults who have relevant skills, including technical and vocational skills for employment, decent jobs and entrepreneurship.

In the Paris Agreement, national governments commit to a path towards low greenhouse gas emissions (holding the increase in global average temperature below 2 degrees above pre-industrial levels) and climate-resilient development and the finance to support these.

One of the hot issues in discussions of the SDGs, the Paris Agreement and now the New Urban Agenda is the extent to which local governments should be considered as leaders in making and addressing the commitments and the extent to which national governments allow (or actually support) this. City governments are not recognised as part of 'government' at inter-governmental meetings within the UN. Official development assistance agencies can only fund city governments with the approval of national governments. Achieving most of the commitments in these three agendas depends heavily on city or municipal governments and local civil society - but these were not allowed to help draft these commitments. So there are lots of broad national commitments and little stimulus to guide the implementation (Hardoy 2017).

But local governments are becoming more organised, in recognising the need to influence how global, and national commitments translate into local commitments that are part of their responsibilities. Within this is the growth of networks of urban governments (or local governments) to press their priorities; to demand that they are a key part of 'government' not just one among many stakeholders (as in many international documents and discussions), and to be recognised not just as 'implementers' but as key actors in setting and achieving locally determined priorities and contributing to global goals. The prospects of meeting most of the SDGs and the Paris Agreement would be enormously enhanced if local governments were allowed (and encouraged) to make their own commitments to meeting the new goals and to influence national policies and funding systems to support this.

\section{The New Urban Agenda}

The first UN-Habitat Conference in 1976 agreed on a long and detailed text on 'Recommendations for National Action' that included what were then major innovations - including government support for upgrading informal settlements, a commitment to universal provision for safe water and hygienic sanitation/waste disposal and governments capturing the unearned increment in land values. It could be said that this did contain key elements of a New Urban Agenda.

The New Urban Agenda agreed at the third Habitat Conference (the UN Conference on Housing and Sustainable Urban Development) in October 2016 could have been equally innovative - in recognising how much a successful urban agenda depended on urban government and local civil society. It had the two new frameworks (the SDGs and the Paris Agreement) providing the national and international goals and commitments, so it could articulate the much needed 'new urban agenda' through which urban 
governments and civil society could address these goals and commitment. What was needed was a short, precise, action-oriented framework to encourage local governments to commit and to act - as in the Healthy Cities movement, participatory budgeting and the Hyogo and Sendai frameworks for disaster risk reduction. ${ }^{5}$

Instead we got a 23 page 'New Urban Agenda' that has very little that is New and not much that is an Agenda. It is long and repetitive - and much of it is making commitments that have already been made within the SDGs and the Paris Agreement. And it is all about national governments, "we commit" stated 42 times "we will" 87 times. So much of what 'we' (national government) commit to are actually the responsibilities of local government.

Much of the text is incoherent. For instance, the word sustainable appears 136 times in the text - and among the many things that are meant to be sustainable are economic growth, economic transformation, industrialisation, territorial development, economic development, debt management, tourism and infrastructure. A word that is so over-used and used with such ambiguity loses its power.

What it does not have is any commitment to support and work with urban governments and urban civil society. Astonishingly, a document claiming to be the New Urban Agenda has no mention of mayors; no mention of democracy; no mention of urban innovations such as participatory budgeting; no reference to grassroots organisations. The 'poor' are mentioned only in relation to their needs; there is no mention of the innovations in urban agendas driven by slum/shack dweller federations or by other urban social movements; not much on water, sanitation, drainage and health care and nothing on electricity, emergency services, solid waste collection and policing.

\section{Challenges}

The diversity among Commonwealth countries makes it difficult to generalise about challenges facing their local, regional and national governments. But Commonwealth countries had around 879 million urban dwellers in 2015 and this total is projected to grow to 1.3 billion by 2030. Projections also suggest that most of this population growth will be in urban areas - and that the level of urbanisation will rise from $38 \%$ to $45 \%$ in these fifteen years.

Most Commonwealth countries have faced a very rapid growth in their urban populations and many fast growing cities, and it has proved difficult for their governments to keep up (Box 2). Many cities have faced a tenfold increase in their population over the last 40 years. Many larger cities face annual population increases of over 100,000 a year. See also the scale of urban population growth projected

\footnotetext{
${ }^{5}$ More details of these and other 'new urban agendas' are discussed in Satterthwaite (2016a) Editorial: a New Urban Agenda? Environment and Urbanization, 28 (1), 3-12.
} 
for 2015-2030: for India, 10.9 million new urban dwellers a year, for Nigeria 4.8 million, for Pakistan 2.3 million, for Bangladesh 1.9 million, for Tanzania 1.1 million (UN-Habitat 2016).

\section{Box 2: Making markets safe for women and girls - lessons from Port Moresby}

Ensuring that cities are safe spaces for citizens, especially women, is essential for local economic development. City-managed market places are one of the most important areas for women vendors to be able to sell produce and make a livelihood. In an attempt to stem endemic violence and intimidation in and around many city markets in Commonwealth countries, city governments have undertaken a number of initiatives to increase safety and security.

A 2012 UN Women study of Port Moresby, the capital of Papua New Guinea, found that with around $80 \%$ of the vendors in the markets being women and girls, 55\% reported that they had experienced some form of violence and $22 \%$ had experienced more than one incidence of sexual violence while in the markets in the last 12 months, with several reported cases of rape. To address this, the city council has facilitated the establishment of vendors associations, with $50 \%$ representation of women in executive positions, and has reviewed how their budgets are allocated to ensure that the needs of women and men are taken into account across the different municipal departments. The city council is also launching a Safe Cities Behaviour Change Campaign which has five components: reformed and enhanced systems to prevent and reduce violence in public spaces; enhanced capacity of duty bearers and agents of change to prevent and respond to violence against women and girls; increased respect amongst market users for women's and girls' rights to a life free from violence; gender sensitive infrastructure and social planning measures; and, capacity building for media to report and cover issues of violence against women and girls and provide information about services available.

Source: UN Women (2012) Making Port Moresby Safer for Women and Girls

In most cities in low- and middle-income nations, a large part of the growth in their populations over recent decades has been in informal settlements. Local governments or national utilities often refuse to provide infrastructure and services to these or they are prevented by law from doing so. It is common for cities to have $30-60 \%$ of their population in informal settlements - and some have even higher percentages. This helps explain the very large deficits in provision in urban areas for key infrastructure. In 2015, 400 million urban dwellers in the Commonwealth lacked a drinking water source piped to their home and 315 million lacked even rudimentary provision for sanitation. According to UN-Habitat (2016), 255 million lived in 'slums' in 2014. In this year, India had 98 million slum dwellers, Nigeria 42 million, Bangladesh 29 million - and Cameroon, Ghana, Kenya, Mozambique, South Africa and Tanzania between 4 and 8 million. ${ }^{6}$ Figure 1 shows the percentage of the urban population with water piped on premises in 2015 - and note the very large deficits in provision for many nations. Figure 2 shows nations that have gone backwards on provision for water piped on premises, as they had a lower proportion of their urban population with access in 2015 than in 1990.

\footnotetext{
${ }^{6}$ This is based on UN-Habitat's definition of slum households - see UN-Habitat (2016). Some governments have their own definition of slums and thus have different figures for their slum population to those coming from the UN.
} 
Figure 1: Percentage of urban population with water piped on premises 2015

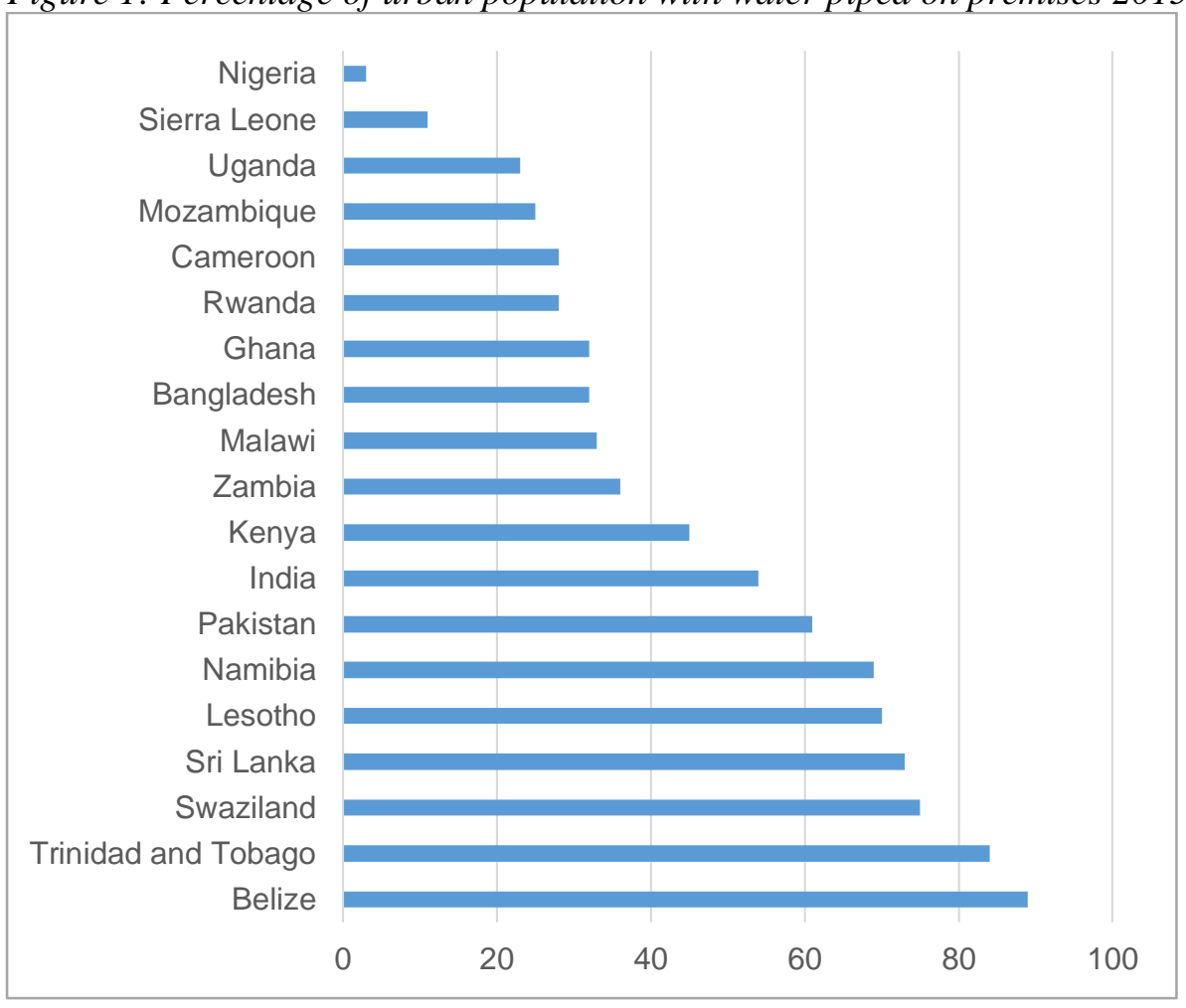

Source: Statistics drawn from UNICEF and WHO (2015)

Figure 2: Nations with a decline in percentage of their urban population with water piped on premises 1990-2015

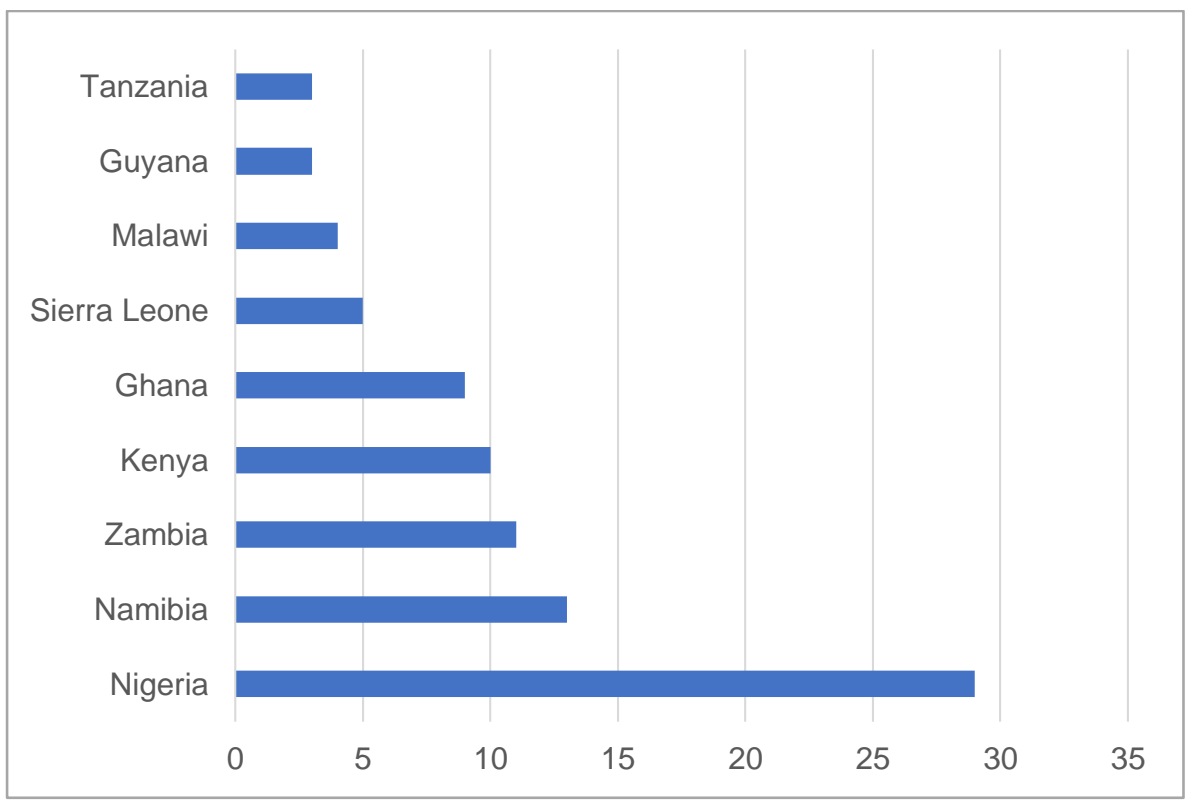

Source: Statistics drawn from UNICEF and WHO (2015)

One of the most pressing challenges for addressing the SDGs in urban areas is having urban governments with the technical capacity and the finance needed to act on the goals - including act on the deficits made evident in Figures 1 and 2. It is a little humbling to recall how all the government representatives attending Habitat I in 1976 made a commitment to universal provision for water and 
sanitation by 1990. But the limited data available on municipal finance shows so many cities and smaller urban centres with little or no investment capacity - and it is generally cities with the largest deficits in infrastructure and services that have the least investment capacity. For instance, for the few cities for which data are available, in sub-Saharan African cities, municipal budgets are the equivalent of between US\$5 and $\$ 50$ per inhabitant (except for South Africa where they are much higher) whereas innovative cities in Latin America have the equivalent of US $\$ 400$ to $\$ 1,300$ per inhabitant. So strengthening the financial base of urban governments has great importance both through decentralisation and through urban governments expanding their own revenues. There is some recognition of this although the wording is vague (Box 3). The New Urban Agenda states that "We support context-sensitive approaches in financing urbanization and in enhancing financial management capacities at all levels of government, adopting specific instruments and mechanisms necessary to achieve sustainable urban development..." (paragraph 131) and "We will mobilize endogenous resources and revenues generated through the capture of benefits of urbanization..." (132) (United Nations (2016).

\section{Box 3: National urban policies}

The New Urban Agenda mentions the need for measures to enable governments to implement National Urban Policies (NUPs) (see paragraph 89). Such policies seek to harness the dynamics of urbanisation and integrate them into the national development strategy. The role of NUPs is not to replace local urban policies, but to assist with harnessing the benefits of urbanisation while mitigating the challenges. This is achieved by helping to align sectoral policies that affect urban areas and by developing an enabling institutional environment. A recent example of such a policy is the 2015 National Urbanisation Policy of Rwanda which facilitates positive urban developments across the country such as improved access to building land, serviced by a series of reforms such as the reallocation of land and the creation of a land bank, the preservation of urban culture and heritage, the introduction of a property tax, funding for public investment, and promoting urban governance.

Source: UN-Habitat, communication with Commonwealth Local Government Forum (CLGF)

The SDGs also stress the need for monitoring government progress and a long list of indicators to do so have been elaborated. But these say little about the huge lack of data on many of these challenges, especially disaggregated data (i.e. data on each locality/ward/small area within urban centres). At present, in most low- and middle-income nations, data collected by governments (e.g. censuses) and international agencies (e.g. demographic and health surveys) do not provide local governments with the data they need to act. National government sample surveys do not have sample sizes large enough to provide relevant disaggregated data to urban governments. Censuses should provide this (as they cover the entire population) but it is rare for census authorities to provide local governments with the census data they need disaggregated to small area units or streets - i.e. what is needed to design and implement the initiatives needed to meet SDG goals. In many countries, to this is added a failure to record deaths and their causes so very high infant, child and maternal mortality rates often go unnoticed. Innovations in information and communications technology (ICT) continue to provide new and cheaper methods for collecting this essential data (Box 4), as well as opportunities to empower communities through 
decentralising data collection, but the ultimate decision to aggregate this data lies with central government.

\section{Box 4: Using technology to manage large infrastructure projects - Auckland}

By 2020, the population of Auckland, New Zealand is expected to expand from 1.4 million to 2.2 million, and Auckland Transport, the agency responsible for the city's public transportation system, has launched more than 200 capital projects ranging from bridges to new bike lanes and massive rail tunnels. Auckland approaches their infrastructure projects from a holistic, strategic perspective, and have partnered with Microsoft SharePoint Server and local partner LeapThought and have adopted a custom digital solution called Fulcrum to manage the 200plus construction projects. Developed by LeapThought, Fulcrum uses the capabilities of the SharePoint Server to provide cross-departmental tools that help manage properties impacted by projects such as the NZ\$2.4 billion (US\$ 1.65 billion), 10-year megaproject City Rail Link. The city is using Fulcrum to keep track of every step in a complicated property acquisition process and enables the sharing of all construction, design, and legal documents related to the project across the project teams and stakeholders. Because Fulcrum uses the capabilities of the SharePoint Server, the city is able to track every stage of a project with complete audit capabilities, and stakeholders can store and share large two- and three-dimensional designs in a central location that can be accessed online. The cost savings and operational efficiencies gained by using Fulcrum on big projects can also extend to smaller capital projects as well and Auckland estimates savings of $\$ 3$ million in the first ten years alone.

Source: Award-winning solution keeps Auckland ahead of the growth curve by Roger Jones, Chief Information Officer, Auckland Transport

\section{Achieving sustainable development}

All definitions of sustainable development are about addressing more than one objective and making different environmental and development objectives work together. Figure 3 illustrates the bringing together of four urban agendas that are emphasised in the SDGs: economic success combined with poverty reduction and universal provision of services (and making this work for the billion living in informal settlements) that then folds into disaster risk reduction and climate change adaptation and mitigation. Other aspects need addressing too - for instance protecting ecosystem services and sustainable water and waste water management, but at least in part these are within these four agendas.

\section{City leadership}

We have many strong examples from high-income Commonwealth countries of innovative cities and of what a functioning local democracy (often with elected mayors) committed to more accountable, transparent and participatory ways of working can do. There are fewer examples of this among lowand middle-income nations, except in Latin America. In this region, city leadership was linked to changes at national level - for most nations, the return to democracy and for many, changes in the constitution to support decentralisation and stronger financial bases for local governments. It is also linked to the region being heavily urbanised. New concepts and approaches were developed - including participatory budgeting that allowed the residents of each district within a city to set priorities for public works and that made the whole government budget more transparent (Cabannes 2004, 2015). 
Figure 3: The four urban agendas and their overlaps
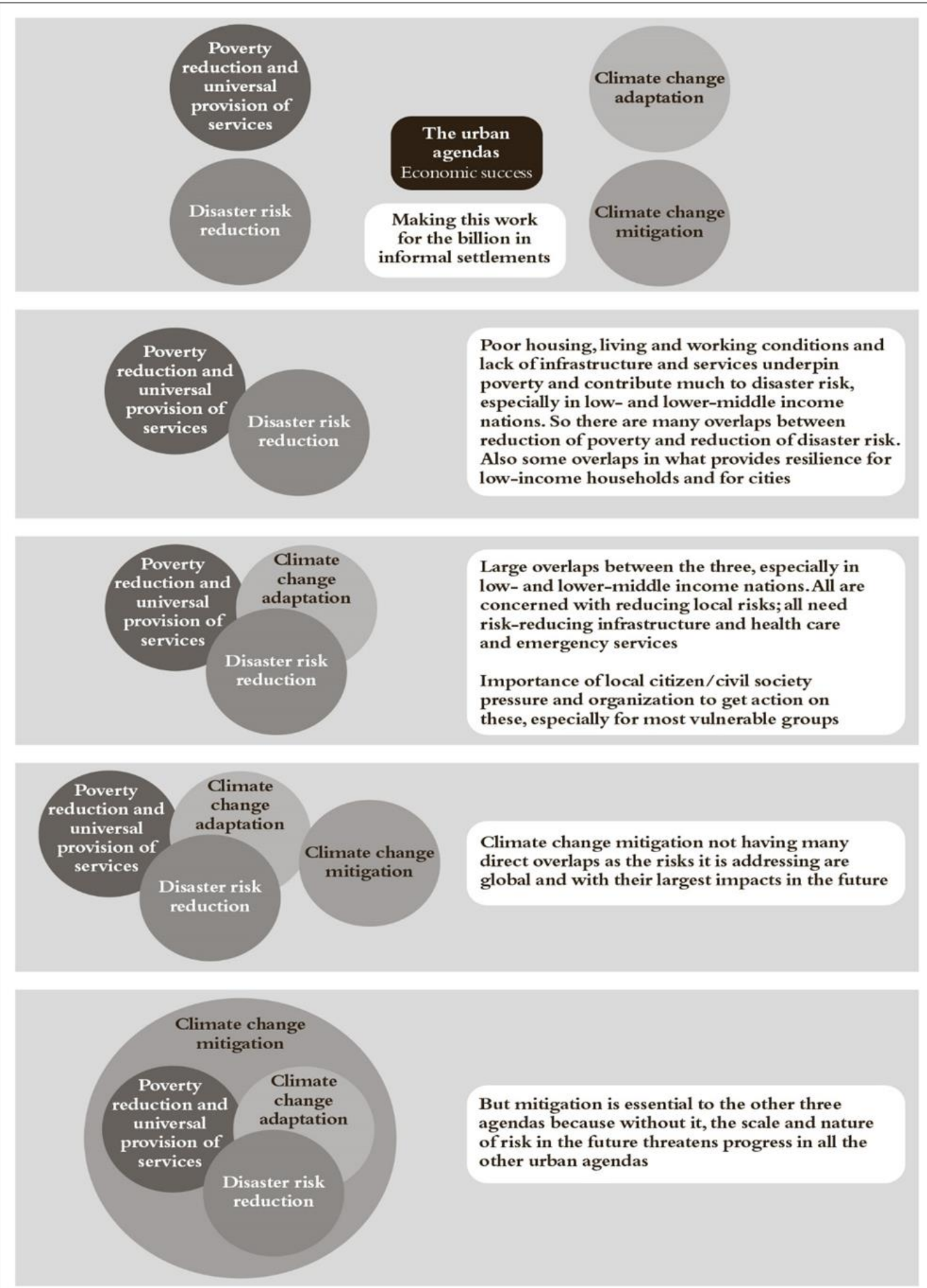

Source: Bartlett and Satterthwaite (2016) 
There has also been city-based innovation and leadership in other regions (Box 5). Among Commonwealth countries in Africa, Durban has been an innovator in linking climate change adaptation and mitigation to development and to promoting and supporting other cities to innovative - for instance through the Durban Adaptation Charter (Roberts et al. 2016). City and municipal governments have also been encouraged and supported to act through their membership of city networks - for instance the Global Taskforce of Local and Regional Governments which supports the work of the Local Authorities Major Group (LAMG), to facilitate the participation of the constituency in UN processes - and also CLGF, UCLG (United Cities and Local Governments), ICLEI (Local Governments for Sustainability, previously the International Council for Local Environmental Initiatives), C-40 (the network of large cities committed to addressing climate change) and the Compact of Mayors.

In many Commonwealth countries, there are also powerful examples of urban poor groups forming their own savings groups in which most savers and savings group managers are women. These then federate to work together and to work collectively with local governments. For instance, there are national federations of slum/shack dwellers in India, South Africa, Namibia, Malawi, Tanzania, Uganda, Kenya, Sierra Leone and Ghana and all seek to work with local governments - for instance in upgrading their settlements or building new homes where land is available. These federations have also developed a capacity to undertake detailed surveys and prepare detailed maps for all informal settlements in a city - information local governments usually lack - that provide the information base to guide interventions. These have been prepared in over 600 cities, most in Commonwealth countries, and advances in ICT present opportunities for further expansion of these types of initiatives. ${ }^{7}$

\section{Box 5: Challenges for city leadership and the issue of capital cities}

In many countries there continues to be a blurring of responsibilities between local and national governments. This is particularly the case in capital cities where national governments often ignore city authority as they carry out their functions, and even more so when there is an opposition party in power at the local level. One of the major areas requiring attention in the Jamaican context has been identified as the overlapping roles of MPs and councillors in local development. Citizens want their roads fixed regardless of who has responsibility. Kingston believes that the local authority is uniquely placed to play the role of facilitator: bringing together different spheres of the public sector, the private sector and civil society. This approach helps to build the credibility of the city council while as partners they enable joined-up governance across a wide range of sectors.

Through regular Town Hall meetings and sector-specific consultations, the council brings stakeholders together to discuss issues affecting citizens, enabling a shared understanding of the needs of the citizens, a clearer understanding of the challenges faced by all concerned and providing an opportunity for suggestions for greater collaboration aimed at increased efficiency and effectiveness. Another key challenge for the city is the lack of appropriate and timely data. For example with the current Zika virus crisis, the Department of Public Health does not automatically share data relating to suspected and confirmed cases in the city with the council, limiting the council's ability to understand and respond to emerging challenges. One of the solutions has been for the City Council to host multi-sector discussions which allow various public sector agencies such as the police, health department and city council to work together to share data, ideas and approaches without being territorial. Creating a culture of shared governance is essential and at times difficult to effect.

Source: Mayor Angela Brown-Burke, Kingston and St Andrew, communication with CLGF

\footnotetext{
${ }^{7}$ See the Know Your City programme described at www.sdinet.org for more details.
} 


\section{Financing and investment}

Achieving the development objectives set out in the SDGs and the New Urban Agenda will require properly resourced cities. Achieving fair and equitable fiscal decentralisation, reduction of unfunded mandates, and improved access to and mobilisation of own source revenue, will be essential in ensuring inclusive equitable urban development. Financing large scale development and infrastructure investment will require access to new and innovative financing mechanisms such as climate change financing and other international funds, development partner funding, as well as partnerships with the private sector through funding mechanisms such as municipal bonds, Public Private Partnerships (PPPs), and aggregated borrowing. Many local governments currently lack the necessary power and have limited human, technical and financial capacity, which will affect their ability to play a full role in the implementation of the SDGs.

\section{Urban planning}

Few urban governments in the low- and middle-income Commonwealth nations have the capacity to plan - or to implement agreed plans - and to manage urban expansion. Managing urban expansion well is central to many of the SDGs, including ensuring an adequate supply of serviced land for new housing, avoiding sprawl and hazardous areas; and protecting watersheds and other ecosystem services (flooding prevention being one key aspect in many cities). There are difficult and often contentious trade-offs that need to be made (e.g. upgrading versus resettlement) and often powerful real estate interests that subvert needed land-use management.

\section{Local economic development (LED)}

This is an approach which brings together different partners in a local area to work together and harness local resources for economic growth. It is becoming increasingly recognised as a function of local government. Although LED is often not a formal statutory requirement, even of urban local government, many of the existing roles and functions of local government (such as the delivery of core services and public goods), together with its democratic legitimacy and role as a community leader and convener, mean that it is well positioned to integrate strategies for economic development into its work. Local governments are increasingly building in an economic development component into their local strategic planning. They can facilitate the necessary strategic and local partnerships e.g. with the private sector and community organisations, to support local economic development in their communities. They can also ensure that they create a strong enabling environment for development through improving the services and quality of life in their communities with long-term investment. They are also well placed to relate directly to other spheres of government, where appropriate, e.g. in electrification.

LED offers a comprehensive framework for 'integrating' and 'localising' the SDGs. Local and regional governments can play a crucial catalytic role as initiators and drivers of effective LED processes, fostering participation, the creation of decent jobs, and the economic empowerment of women, youth 
and vulnerable groups (Box 6). LED contributes to strengthening social trust and cohesion, helping to build societies that are more stable and resilient to growing, complex and widespread risks, preventing conflict, and ensuring sustainable development.

\section{Box 6: City leadership for local economic development in Belize City}

Leadership, both from within the council but also across the local community and the private sector, has been a critical factor in the success of Belize city council's local economic development programme. Spearheaded by the Mayor, the city has focused on building relationships across the community to engage local people in developing a vision for economic growth and development. This has also helped to change the way in which the private sector views the council. The city council's reputation with the private sector has shifted from one of wariness that the council was only interested in collecting their taxes, to one that sees the council as enabling investment and job creation. LED is now part of the Belize City Urban Development Masterplan 2011-2030, has been integrated across all departments and service areas, and a specific LED Unit has been established to implement the strategy.

Source: Mayor Darrell Bradley, Belize City, presentation at the CLGF Caribbean regional meeting 2018

\section{Conclusions}

It is good to see the recognition of the importance of cities to national economies. It has taken a long time for this to be fully recognised. But economic success in any city does not automatically contribute to a healthier and safer city, a more inclusive city (where as the SDGs state no-one is left behind) or a sustainable city. This needs capable and accountable urban governments.

Hundreds of millions of urban dwellers within the Commonwealth have very inadequate incomes and live in poor quality, overcrowded housing that lack basic infrastructure and services. In some nations, there is even a lower proportion of their population with water piped to premises now than they had in 1990 (Satterthwaite 2016b). So they actually went backwards on some of their commitments.

Most Commonwealth countries have faced a rapid growth in their urban populations in recent decades and they have not managed to develop the national and local governance structures to allow them to keep up. Projections suggest a growth in the urban population of the Commonwealth of 400 million in the next 15 years. We noted earlier the scale of urban population growth projected for 2015-2030 that included 10.9 million new urban dwellers a year for India and 4.8 million a year for Nigeria. Will these simply get added to the population in informal settlements lacking services? Now, to this governance and service provision challenge is added the need to adapt all urban centres and systems to operate within regional and global resource limits, build resilience to the increasing risks climate change is bringing AND contribute to greenhouse gas emissions reduction.

When seen in aggregate, this seems impossible. But if seen as spread across the tens of thousands of urban centres within Commonwealth countries it seems less daunting. But this requires urban (municipal and metropolitan) governments with the capacity to govern well, to act, to mobilise resources - addressing local needs (and being accountable to local populations, especially those who 
are most likely to be left behind) and folding into this disaster risk reduction and climate change adaptation and mitigation. We know this is possible as it has been demonstrated in many cities (Bartlett and Satterthwaite 2016). But these cities and towns are the outliers; the ones that have succeeded. It is in getting comparable innovation among most or all urban governments that is the basis for meeting the SDGs, the Paris Agreement and the New Urban Agenda. But this is a challenge to national governments because effective local governments depend on supportive and appropriate legislation, rules and regulations (planning, health and safety, building standards, disaster risk reduction, climate change ...) and systems of devolved finance. Success or failure to achieve genuine multi-level governance will significantly impact on countries' abilities to achieve sustainable development.

As noted above, we do not need more goals. What we need is the capacity and willingness in each urban government to respond to local needs and priorities, within the framework of the local and global goals to which national governments have already committed.

We did not need a New Urban Agenda that repeated the goals already present in the SDGs and the Paris Agreement. What is needed is an urban agenda that speaks to local governments and local civil society in which their needs and priorities are evident, with local and global goals to which local governments can commit. The commitment that national governments should have made is "We commit to supporting urban governments to develop their responses to the SDGs and the Paris Agreement within their jurisdiction and to work with them so no-one is left behind." This means shifting attention from defining goals to creating the institutional and governance basis for achieving goals already committed to in each locality.

The two most important actors for getting the SDGs, the Paris Agreement and the New Urban Agenda addressed in urban areas are urban governments and local civil society (especially representative organisations of the urban poor whose unmet needs the SDGs are meant to address). So we need to look to changes in what national government and international agencies do to support them.

International development assistance agencies are only as effective as the local intermediaries through which their funding flows. The key issue is thus how to increase and enhance support to these two actors. Local funds are needed that they can draw on and that are managed in ways that are transparent and accountable downwards to their population, as well as upwards to higher levels of government and horizontally to the stakeholders, funders and other actors active in the urban territory. Development assistance is legitimated on the basis of it addressing the needs of urban (and rural) poor groups. It is time it developed local funding mechanisms to support them and accountability to them. 


\section{References}

Bartlett, S. and Satterthwaite, D. (eds) (2016) Cities on a finite planet: Towards transformative responses to climate change. London: Routledge.

Cabannes, Y. (2004) Participatory budgeting: A significant contribution to participatory democracy. Environment and Urbanization, 16 (1), 27-46. doi: https://doi.org/10.1630/095624704323026133 and https://doi.org/10.1177/095624780401600104

Cabannes, Y. (2015) The impact of participatory budgeting on basic services: Municipal practices and evidence from the field. Environment and Urbanization, 27 (1), 257-284. doi: https://doi.org/10.1177/0956247815572297

Hardoy. J. (2017) An urban development agenda for Latin American cities: Integrating global and local challenges. Available at: https://ugecviewpoints.wordpress.com/2017/01/31/an-urban-developmentagenda-for-latin-american-cities-integrating-global-and-local-challenges/

Jones, R. (2015) Award winning solution keeps Auckland ahead of the growth curve. Microsoft CityNext. Available at: https://enterprise.microsoft.com/en-us/industries/citynext/award-winning-solution-keepsauckland-ahead-of-the-growth-curve/

Roberts, D., Morgan, D., O’Donoghue, S., Guastella, L., Hlongwa, N., Price, P. (2016) Durban, South Africa. In: Bartlett, S. and Satterthwaite, D. (eds) Cities on a finite planet: Towards transformative responses to climate change (pp. 96-115). London: Routledge.

Satterthwaite, D. (2016a) Editorial: A new urban agenda? Environment and Urbanization, 28 (1), 3-12. doi: https://doi.org/10.1177/0956247816637501

Satterthwaite, D. (2016b) Missing the millennium development goal targets for water and sanitation in urban areas. Environment and Urbanization, 28 (1), 99-118. doi: https://doi.org/10.1177/0956247816628435

United Cities and Local Governments. (UCLG) (2014) Basic services for all in an urbanizing world; the third global report on local democracy and decentralization. London: Routledge.

UNICEF and World Health Organization (2015) 25 years progress on sanitation and drinking water: 2015 update and MDG assessment. New York, USA: UNICEF/WHO.

UN-Habitat. (2016) World cities report 2016: Urbanization and development: Emerging futures. Nairobi: United Nations Human Settlements Programme.

United Nations. (2015) Transforming our world: The 2030 Agenda for Sustainable Development. Available at: https://sustainabledevelopment.un.org/sdgs [Accessed December 2016].

United Nations. (2016) New Urban Agenda. Available at: http://habitat3.org/wp-content/uploads/N1639668English.pdf

UN Women (2012) Making Port Moresby safer for women and girls. Available at: http://asiapacific.unwomen.org/en/digital-library/publications/2012/9/making-port-moresby-safer-forwomen-and-girls [Accessed December 2016]. 